\title{
Xenoestrogens modulate vascular endothelial growth factor secretion in breast cancer cells through an estrogen receptor-dependent mechanism
}

\author{
Hélène Buteau-Lozano ${ }^{1,2}$, Guillaume Velasco ${ }^{1,2}$, Monique Cristofari ${ }^{1,2}$, Patrick Balaguer $^{3}$ \\ and Martine Perrot-Applanat ${ }^{1,2}$ \\ ${ }^{1}$ INSERM, U553, Hémostase, Endothélium et Angiogénèse, Hôpital Saint Louis, 1 Avenue Claude Vellefaux, 75475 Paris Cedex 10, France \\ ${ }^{2}$ IFR105 Université Paris 7, 75000 Paris, France \\ ${ }^{3}$ INSERM, U824, Signalisation hormonale, Environnement et Cancer, 34098 Montpellier, France \\ (Correspondence should be addressed to M Perrot-Applanat; Email: martine.applanat@stlouis.inserm.fr)
}

\begin{abstract}
Environmental chemicals may affect human health by disrupting endocrine function. Their possible role in the mammary gland and breast tumors is still unknown. Previous studies have demonstrated that vascular endothelial growth factor (VEGF), a key factor in angiogenesis and tumor progression, is an estrogenregulated gene. We analyzed whether VEGF expression is regulated by different xenoestrogens in several breast cancer cells, MELN (derived from MCF-7) and MELP (derived from MDAMB-231) and stably expressing estrogen receptor $\alpha(\operatorname{ER} \alpha)$; these cell lines stably express estrogen response element ( $\beta$-globin)luciferase. Genistein, bisphenol A (BPA), 4-(tert-octyl)phenol $(\mathrm{OP})$, dieldrin, and several phthalates, including benzyl butyl phthalate (BBP) and di-ethyl-2-hexyle phthalate (DEHP), were first shown to be estrogenic. These compounds induced a dosedependent increase of VEGF secretion in MELN and MCF-7 cells; maximal effect was observed at 1-10 $\mu \mathrm{M}$ non-cytotoxic concentrations and was inhibited by the antiestrogen ICI
\end{abstract}

182780 . VEGF increase was not observed in ER $\alpha$-negative MDA-MB-231 cells. Most substances increased VEGF transcript levels in MELN cells. In contrast, $\gamma$-hexachlorocyclohexane, vinclozolin, and the phthalates (mono- $n$-butyl ester phthalic acid, di-isononyle phthalate, and di-isodecyle phthalate) were ineffective on both VEGF secretion and estrogenic luciferase induction in these cell lines. Specific kinase inhibitors PD98059, SB203580, or LY294002 suppressed the xenoestrogen-induced VEGF response, suggesting activation of MEK, p38 kinase, and phosphatidylinositol-3-kinase pathways. Our in vitro results show for the first time that genistein and xenoestrogens (BPA, OP, dieldrin, BBP, and DEHP at high concentrations) up-regulate VEGF expression in MELN cells by an ER-dependent mechanism. Since VEGF increases capillary permeability and breast tumor angiogenesis in vivo, the physiological relevance of these findings is discussed.

Journal of Endocrinology (2008) 196, 399-412

\section{Introduction}

Over the past 20 years, a great deal of attention has focused on the impact of endocrine disruptors released in the environment on animal and human health. A large number of these environmental pollutants, including alkylphenol compounds, polychlorinated biphenyls (PCBs), polychlorinated dibenzodioxins, organochlorine pesticides, and bisphenol A (BPA), have been shown or suspected to disrupt endocrine functions in animals. Generally, endocrine disruptors have estrogenic activity (so-called xenoestrogens including pesticides, bisphenols and alkylphenols, some PCBs, and phthalates; Colburn 1995, Jobling et al. 1995, Soto et al. 1995, Sonnenschein \& Soto 1998, Andersen et al. 1999), anti-androgenic activity (some pesticides; Colburn 1995, Kelce et al. 1997), or disrupt thyroid function (PCBs, perchlorate, and some pesticides) (Koopman-Esseboom et al. 1994). Although xenoestrogens are generally less potent than endogenous estrogens when tested in biological assays, they are cause of concern due to their persistence in the environment, resistance to chemical or enzymatic degradation, and sequestration and storage in the adipose tissue. Whether it can be implied that these substances in human female reproductive diseases (precocious puberty and endometriosis, Teilmann et al. 2002) or in steroid hormone-dependent cancers (breast, prostate) are a leading cause of mortality and morbidity in industrialized countries, is still under debate (Sasco 2001, Birnbaum \& Fenton 2003, Mitra et al. 2004, Sharpe \& Irvine 2004, Safe 2005).

Development of the mammary gland and breast cancer in women depends on diverse factors including exposure to estrogens (Jordan \& Murphy 1990). Estrogens regulate cell function through tissue-dependent specific intracellular receptors (estrogen receptor, ER), acting as ligand-activated transcription factors. Activated ERs regulate the expression of many genes via direct interaction with an estrogen response 
element (ERE) sequence located in the promoter or via interaction with other transcription factors, such as members of activator protein-1 (AP-1), signal transducer and activator of transcription (STATs), nuclear factor-kappa B (NF- $\mathrm{B})$, and specificity protein (SP-1) families (Stein \& Yang 1995, Paech et al. 1997). Selective effects of estrogens may be modulated by the receptor subtype $(\mathrm{ER} \alpha$ or $\mathrm{ER} \beta)$, the relative expression of each receptor in a target tissue, and the promoter context of estrogen-regulated genes (Carson-Jurica et al. 1990, Kuiper et al. 1997, Paech et al. 1997). The transcriptional modulation arises from an interplay of interactions between co-activators and co-repressors that determine the specificity of hormone action in the different tissues, a feature particularly highlighted by the puzzling pharmacology of selective ER modulators (SERMs), acting as receptor agonist or antagonist depending on the target organ. Whether xenoestrogens, which can accumulate in adipose tissue, may play a role in the incidence or progression of breast tumors, is largely unknown. A few epidemiological studies have reported a correlation between exposure to some xenobiotics and increased incidence of tumors, including breast cancers (Hoyer et al. 1998, Mills 1998, Sasco 2001, Hopenhayn-Rich et al. 2002, Birnbaum \& Fenton 2003, Mitra et al. 2004). Prenatal exposure to endocrine disruptors, including BPA, atrazine, and 2,3,7,8-tetrachlorodibenzo-p-dioxin (TCDD), has been shown to alter the development of the rodent mammary gland, and the susceptibility to further carcinogenic exposure in adulthood (Brown et al. 1998, Markey et al. 2001, Birnbaum \& Fenton 2003, Fukamachi et al. 2004).

The complexity of xenoestrogen action in vitro, and in several physiopathological conditions, has not been well understood, especially due to the limited use and knowledge of estrogenresponsive genes. In vitro investigations of the molecular mechanism of xenoestrogen effects have been focused on the proliferation test of ER $\alpha$-expressing $\mathrm{MCF}-7$ cells, binding assays with ERs ( $\alpha$ and $\beta$ ), reporter gene assays using ERE (Soto et al. 1995, Kuiper et al. 1997, Andersen et al. 1999, Legler et al. 1999, Balaguer et al. 2001, Diel et al. 2002, Olsen et al. 2003), or a few estrogen target gene promoters (Hall \& Korach 2002). Recently, a DNA microarray was also developed to evaluate the estrogenic activity of industrial chemicals (Terasaka et al. 2004). The identification of estrogen target genes is clearly needed to assess the complexity of xenoestrogen action in vitro and in physiopathological conditions.

Numerous studies have indicated that estrogen and progesterone are the stimuli of vascular endothelial growth factor (VEGF) expression in breast cancer cells and tumors (Nakamura et al. 1996, Hyder et al. 1998, Ruohola et al. 1999, Buteau-Lozano et al. 2002, Stoner et al. 2004). VEGF is a permeability and key angiogenic factor, which stimulates endothelial cell proliferation and migration in vitro and in vivo (Ferrara \& Davis-Smith 1997). VEGF is expressed by the human mammary gland (Dabrosin 2003), and its expression increases in breast tumors depending on the microenvironment. In vitro, numerous studies have shown that $17 \beta$-estradiol $\left(\mathrm{E}_{2}\right)$ increases VEGF expression in breast cancer cells (Ruohola et al. 1999, Buteau-Lozano et al. 2002, Stoner et al. 2004). In vivo, VEGF expression has been shown to be rapidly induced by $\mathrm{E}_{2}$ in the uterus, vagina, and pituitary (Cullinan-Bove \& Koos 1993, Shifren et al. 1996, Bausero et al. 1998, Kazi et al. 2005) and in rodent and primate models of mammary cancer (Nakamura et al. 1996, Dabrosin et al. 2003). Interestingly, the xenoestrogen BPA also increases VEGF expression in the uterus (Long et al. 2001). However, whether the expression of VEGF, which is a key factor in tumor angiogenesis, is modulated by xenoestrogens in breast cancer is not known. Therefore, we hypothesized that xenoestrogens could modulate VEGF expression in estrogen-dependent breast cancer cells.

In the present study, we tested several known and potential ER agonists (xenoestrogens) for their ability to induce VEGF expression in different breast epithelial cells. We used several cellular models: i) MCF-7 cells; ii) MELN derived from MCF-7 cells (Balaguer et al. 2001), which express endogenous ER $\alpha$; and iii) MELP derived from MDA-MB-231 cells, which stably express ER $\alpha$. Both MELN and MELP express ERE-coupled luciferase gene, allowing us to combine the analysis of endogenous VEGF expression and the induction of the ERE reporter gene by different compounds in the same cells and between cells. We analyzed the effects of the phytoestrogen genistein; BPA; 4-(tert-octyl)phenol (OP); several pesticides including dieldrin, $\gamma$-hexachlorocyclohexane $(\gamma \mathrm{HCH})$, vinclozolin, and the herbicide atrazine; and several phthalates including benzyl butyl phthalate (BBP), mono- $n$-butyl ester phthalic acid (MBuP), di-ethyl-2-hexyle phthalate (DEHP), di-isononyle phthalate (DINP), and di-isodecyle phthalate (DIDP). We analyzed some of the mechanisms of VEGF regulation, such as ER-dependent activation pathway and/or activation of kinases.

\section{Materials and Methods}

\section{Hormones and chemicals}

$\mathrm{E}_{2}$, genistein (Gen), BPA (purity 99\%), OP (purity 97\%), lindane $(1,2,3,4,5,6 \mathrm{\gamma HCH}$, purity $97 \%)$, dieldrin (purity $94 \%$ ), vinclozolin (VIN, purity 99.6\%), and atrazine (ATZ, purity $99 \cdot 2 \%$ ) were purchased from Sigma or Sigma-Aldrich (GmbH, D-30918). MBuP (purity 98\%) was purchased from Interchim (Tokyo Chemical Industry, Tokyo, Japan). BBP (purity 98\%), DEHP (purity 99.5\%), DINP (purity 99.9\%), and DIDP (purity 99.9\%) were gifts from Arkema (Paris, France). ICI 182780 (ICI) was provided from Astrazeneca (Macclesfield, Cheshire, England). $\mathrm{E}_{2}$ and BPA were dissolved in ethanol. All other compounds were dissolved in dimethyl sulfoxide (DMSO). The kinase inhibitors PD98059 (PD), SB203580 (SB), Ly294002 (Ly), and wortmaninn (W) were obtained from Calbiochem (San Diego, CA, USA).

\section{Breast cancer cells}

Human breast cancer cell line MCF-7 and MDA-MB-231 cells were obtained from the American Type Culture Collection. MCF-7 cells express ER $\alpha$ and are growth responsive to estrogens. They were routinely maintained in Dulbecco's 
modified Eagle's medium/Ham's Nutrient mixture F12 (DMEM/F12, Gibco Life Technologies Inc.), supplemented with 10\% fetal bovine serum (FBS, Life Technologies), 100 units/ml penicillin/streptomycin (PS), and $250 \mu \mathrm{g} / \mathrm{ml}$ amphotericin B (Gibco-BRL), as previously described (Buteau-Lozano et al. 2002). ER $\boldsymbol{\alpha}$-negative MDA-MB-231 cells were routinely maintained in DMEM supplemented with $10 \%$ FBS, 100 units $/ \mathrm{ml} \mathrm{PS}$, and $100 \mu \mathrm{g} / \mu \mathrm{l}$ sodium pyruvate.

The stable human breast cancer cell lines MELN (derived from MCF-7 cells) or MELP (derived from MDA-MB-231 cells and transfected with ER $\alpha$ ) express the estrogen-responsive construct ERE ( $\beta$-globin)-luciferase previously described (Balaguer et al. 2001). MELN and MELP express around 200 and 50 fmoles ER $\alpha / \mathrm{mg}$ protein respectively. These cells were routinely maintained in DMEM with phenol red, supplemented with 10\% FBS and selective antibiotics, either neomycin $(500 \mu \mathrm{g} / \mathrm{ml})$ for MELN or puromycin $(0.5 \mu \mathrm{g} / \mathrm{ml})$ for MELP.

\section{Cell treatment}

Cells were seeded in 12-well plates at an initial concentration of 50000 cells per well in a $5 \% \mathrm{CO}_{2}$ atmosphere at $37^{\circ} \mathrm{C}$. Prior to cell treatment, cells were cultured in phenol red-free DMEM supplemented with 5\% csFBS (charcoal-stripped FBS) for 3 days, and then starved overnight in serum-free medium. The following day, treatments consisted of vehicle (ethanol or DMSO at $0 \cdot 1 \%), \mathrm{E}_{2}\left(10^{-12}\right.$ to $\left.10^{-6} \mathrm{M}\right)$, or different compounds $\left(10^{-10}\right.$ to $\left.10^{-4} \mathrm{M}\right)$ for a further $24 \mathrm{~h}$. Chemical substances were diluted to the desired concentration in culture medium immediately before use. To test the effect of the kinase inhibitors, cells were pretreated for $2 \mathrm{~h}$ with PD98059 $(20 \mu \mathrm{M})$, SB203580 $(10 \mu \mathrm{M})$, LY294002 $(25 \mu \mathrm{M})$, and wortmaninn $(0 \cdot 1 \mu \mathrm{M})$ before stimulation with compounds.

\section{Determination of cell viability}

Cells were plated into $96-$ well plates $\left(5 \times 10^{3} /\right.$ well $)$ in complete DMEM at $37^{\circ} \mathrm{C}, 5 \% \mathrm{CO}_{2}$. Prior to cell treatment, cells were cultured in phenol red-free DMEM supplemented with 5\% FBS for 3 days, and then starved overnight in serumfree medium. Cells were then treated for $24 \mathrm{~h}$ with vehicle or increasing concentrations of xenoestrogens. Metabolic activity was analyzed using the colorimetric XTT assay (Roche Diagnostics, Herve et al. 2005).

\section{Human VEGF immunoassay}

VEGF levels were measured from the conditioned media using a Quantikine kit from R\&D Diagnostics (Abingdon, UK). They were normalized to the protein concentration in each dish, using BCA protein assay. Results were calculated as pg of VEGF per mg of total proteins (Buteau-Lozano et al. 2002). Results are expressed as percentages of VEGF expression (mean \pm s.E.M. for a minimum of three separate experiments performed in triplicate). The $100 \%$ value represents the value obtained in the presence of $1 \mathrm{nM} \mathrm{E}_{2}$.

\section{Luciferase assay}

Cells once washed with PBS were lysed with reporter lysis buffer as previously described (Buteau-Lozano et al. 2002). Luciferase activities were determined using the Luciferase Reporter Assay system (Promega) and were normalized to the protein concentration measured in the respective cell extracts. Fold induction represents the ratio between values obtained from compounds-stimulated versus control cells. Results are expressed as a percentage of activity, using the value obtained in the presence of $1 \mathrm{nM} \mathrm{E}_{2}$ as $100 \%$ value.

\section{$R N A$ extraction and RT-PCR analysis}

Total RNA was isolated from MELN cultured cells using the TRIzol method (Life Technologies Inc.) according to the manufacturer's procedure and previously described (Ancelin et al. 2002). Transcript quantification of $V E G F A$ and of its three major isoforms, i.e., VEGF121, VEGF165, and VEGF189, was determined by real-time quantitative RT-PCR as previously described (Bieche et al. 2004), using the TATA box-binding protein $(T B P)$ as an endogenous RNA control. Each sample was normalized on the basis of its TBP content. Results are expressed as $\mathrm{N}$-fold differences in target gene expression relative to TBP gene expression. The nucleotide sequences of the oligonucleotide primers are shown in Table 1. To avoid amplification of contaminating genomic DNA, one of

Table 1 Oligonucleotide primer sequences used

\begin{tabular}{|c|c|c|c|}
\hline & Oligonucleotides & Sequence & PCR product size $(\mathrm{pb})$ \\
\hline \multicolumn{4}{|l|}{ Gene } \\
\hline \multirow[t]{2}{*}{ VEGFA } & Upper primer & 5'-CTT GCC TTG CTG СТC ТАC СТC C-3' & 103 \\
\hline & Lower primer & 5'-CAT CCA TGA ACT TCA CCA CTT CGT-3' & \\
\hline \multirow[t]{2}{*}{ VEGF121 } & Upper primer & $5^{\prime}$-ACC TCA CCA AGG CCA GCA CAT A-3 $3^{\prime}$ & 110 \\
\hline & Lower primer & 5'-GCC TCG GCT TGT CAC ATT TTT CT-3' & \\
\hline \multirow[t]{2}{*}{ VEGF165 } & Upper primer & $5^{\prime}$-СCT CAC CAA GGC CAG CAC ATA-3' & 107 \\
\hline & Lower primer & 5'-CAA GGC CCA CAG GGA TTT TCT-3' & \\
\hline \multirow[t]{2}{*}{ VEGF189 } & Upper primer & 5'-TAA GTC CTG GAG CGT TCC CTG T-3' & 112 \\
\hline & Lower primer & 5'-CTT GCA ACG CGA GTC TGT GTT T-3' & \\
\hline \multirow[t]{2}{*}{ TBP } & Upper primer & $5^{\prime}$-TGC ACA GGA GCC AAG AGT GAA-3' & 132 \\
\hline & Lower primer & $5^{\prime}$-CAC ATC ACA GCT CCC CAC CA-3' & \\
\hline
\end{tabular}


the two primers was placed at the junction between two exons. The specificity of PCR amplicons was checked by agarose gel electrophoresis. PCR was performed using the SYBR Green PCR Core Reagents kit (Perkin-Elmer Applied Biosystems, Foster City, CA, USA). The experiments were performed with duplicates for each data point.

\section{Statistical analysis}

Statistical significance was assessed using a two-tailed Student's test or a general linear model ANOVA. $P<0 \cdot 05$ was considered to indicate a statistically significant difference.

\section{Results}

The breast cancer MELN and MELP cell lines can be successfully used to evaluate the estrogenic activity of chemical substances, using the ERE pathway (Balaguer et al. 2001). We have therefore used these cell lines to analyze the effects of several chemical compounds on ER-mediated luciferase induction and on VEGF expression. The chemical compounds that we have tested are the phytoestrogen genistein, pesticides or herbicides (dieldrin, atrazine, vinclozolin, and $\gamma \mathrm{HCH}$ ), phthalates (DEHP, BBP, MBuP, DINP, and DIDP), BPA, and OP.

\section{Estrogenic activity of xenoestrogens in stable breast cell lines} $M E L N$ and MELP

The effects of genistein and several chemical compounds on ER-mediated luciferase induction in breast cancer cells are shown in Fig. 1. $E_{2}$ and genistein significantly increased EREdriven luciferase activity in a dose-dependent manner (Fig. 1A and $\mathrm{E})$, with a maximal stimulation at $10^{-9} \mathrm{M}$ for $\mathrm{E}_{2}(7 \cdot 8-$ and 4.8-fold induction in MELN and MELP respectively) and $10^{-6} \mathrm{M}$ for genistein $(10 \cdot 5$ - and 3.8-fold induction in MELN and MELP respectively; Fig. 1). Among the chemical compounds, BPA, OP, BBP, and DEHP increased ERE-luc activity in both cell lines in a dose-dependent manner. The effect is observed at $10^{-6}$ and $10^{-5} \mathrm{M}$ for BPA in MELN and MELP (9.6- and 4.2-fold induction respectively; Fig. $1 \mathrm{~B}$ and F). OP, BBP, DEHP, and dieldrin increased ERE-driven luciferase activity at $10^{-6} \mathrm{M}$ to $10^{-5} \mathrm{M}$ (Fig. $1 \mathrm{~B}, \mathrm{C}, \mathrm{F}$ and G). Maximal effect of BBP was clearly observed in both assays at $10^{-5}$ to $10^{-4} \mathrm{M}$ (Fig. 1C and G). A strong effect for dieldrin was clearly observed at $10^{-5} \mathrm{M}$ in MELN (Fig. 1D). Weak, but significant, effect was observed with DEHP in MELN (1.6- to 1.9-fold induction). The range of estrogenic activity was as follows: $\mathrm{E}_{2}>$ genistein $>\mathrm{BPA}>\mathrm{OP}$, dieldrin, $\mathrm{BBP}>\mathrm{DEHP}$. $\gamma \mathrm{HCH}$, vinclozolin, atrazine and phthalates (MBuP, DINP, and DIDP) were ineffective on luciferase induction in both cell lines (see Fig. 1C, D, G and $\mathrm{H}$ ). Our results indicate that the chemical compounds, BPA, OP, BBP, and DEHP, and the pesticide dieldrin have estrogenic activity in these two mammary cell lines. These results are consistent with previous results using MELN or HELN ER $\alpha$ (Balaguer et al. 1999, Paris et al. 2002). In addition, as observed for $\mathrm{E}_{2}$ activity, the estrogenic activity of xenoestrogens is higher in the MELN than in the MELP cell line, as deduced from results expressed in fold induction.

Cell viability The potential toxicity of xenoestrogens used in these experiments was assessed using cell viability and protein assays. Cell viability assay indicated no toxicity effect of these compounds used at $10^{-5} \mathrm{M}$ (Fig. 2). In addition, protein levels were unchanged during the course of these experiments.

\section{Modulation of VEGF expression by genistein and xenobiotics in two breast cancer cell lines}

To determine whether the expression of VEGF transcripts is regulated by xenoestrogens, MELN cells were treated with different compounds at concentrations that induced the maximal transactivation in the ERE-Luc assay (see Fig. 1). VEGF mRNA production was first assessed using quantitative RT-PCR, as described in Materials and Methods. $\mathrm{E}_{2}$, genistein, and xenoestrogens including BPA, BBP, and dieldrin produced an increase of VEGF isoform transcripts after 6-h stimulation (Fig. 3). Interestingly, a similar increase of both VEGF121 and 165 transcripts, corresponding to the predominant isoforms, was observed after 6-h stimulation in MELN cells compared with control cells (Fig. 3A and B). The increase of VEGF transcripts was also observed at 2-4 h (not shown). No significant effect was observed with OP and DEHP in these conditions. The levels of VEGF transcripts obtained after xenoestrogen stimulation was fully decreased in the presence of the specific antiestrogen ICI 182780 (Fig. 3D).

We further tested whether the same chemical compounds induce VEGF protein expression in these cell lines. Cells were exposed to various concentrations of $\mathrm{E}_{2}$ or xenoestrogens for $24 \mathrm{~h}$. In MELN cell line, $\mathrm{E}_{2}$ induces VEGF secretion at the low concentration of $10^{-10}$ to $10^{-9} \mathrm{M}(2 \cdot 4$-fold induction). We observed a dose-dependent increase in VEGF secretion with genistein, with maximal activation at $10^{-7} \mathrm{M}(2 \cdot 5$-fold induction; Fig. 4A and E). Among the xenobiotics, BPA and OP, dieldrin, $\mathrm{BBP}$, and, to a lesser extent, DEHP increased significantly VEGF secretion at high concentrations (Fig. 4). Maximal effect was observed at $10^{-6} \mathrm{M}$ for OP and BPA (2- and 1.8-fold induction respectively; Fig. 4B). Among phthalates, BBP increased significantly VEGF expression at $10^{-6} \mathrm{M}$ to $10^{-4} \mathrm{M}(2 \cdot 2$-fold induction at $10^{-5} \mathrm{M}$; Figs $4 \mathrm{C}$ and $5 \mathrm{~A}$ ) and significant effect was observed for DEHP at $10^{-5} \mathrm{M}$ (1.9-fold induction). Among pesticides, only dieldrin increased significantly VEGF secretion, with a maximal effect at $10^{-5} \mathrm{M}(1 \cdot 8$-fold induction). All these compounds increased VEGF secretion at 4-24 h. In contrast, the pesticides $\gamma \mathrm{HCH}$, vinclozolin and atrazine, and the phthalates (MBuP, DINP, and DIDP) were ineffective on VEGF secretion (Fig. 4C and D), even at high concentration (Fig. 5A).

In MELP, a significant increase in VEGF secretion was observed with $\mathrm{E}_{2}$ at $10^{-10}$ to $10^{-9} \mathrm{M}$ (1.9-fold induction). While genistein and OP increase VEGF secretion in MELP (Fig. 4E and F), the fold induction was smaller (1.6-fold at $10^{-6} \mathrm{M}$ and $1 \cdot 8$ - at $10^{-5} \mathrm{M}$ for genistein and $\mathrm{OP}$ respectively) 

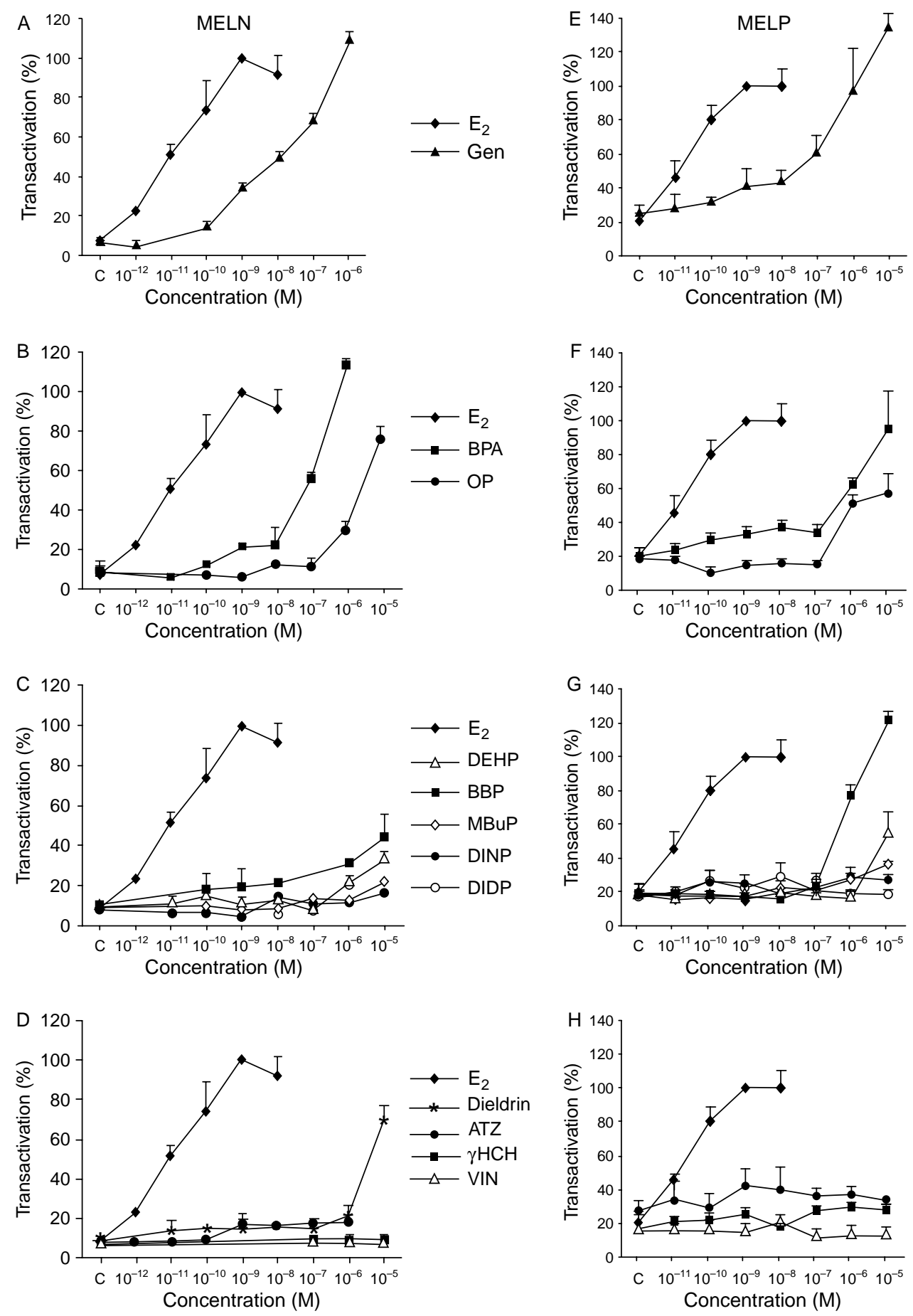

Figure 1 The effect of different environmental chemicals on ER-mediated gene transactivation in MELN and MELP cell lines. Cells were treated for $24 \mathrm{~h}$ with vehicle (ethanol or DMSO) and increasing concentrations of estradiol ( $\left.\mathrm{E}_{2}\right)$, genistein (Gen) (A and E), bisphenol A (BPA), 4-(tertoctyl)phenol (OP) (B and F), di-ethyl-2-hexyle phthalate (DEHP), benzyl butyl phthalate (BBP), mono- $n$-butyl ester phthalic acid (MBuP), di-isononyle phthalate (DINP), di-isodecyle phthalate (DIDP) (C and G), dieldrin, lindane $(\gamma \mathrm{HCH})$, vinclozolin (VIN), or atrazine (ATZ) (D and $\mathrm{H}$ ). Results are expressed as percentages of luciferase activity (mean \pm s.E.M. from at least three separate experiments performed in triplicates for most chemical compounds ( $E_{2}$, Gen, BPA, OP, DEHP, dieldrin, BBP, and MBuP); mean \pm s.D. from a representative experiment performed in triplicates for DINP, DIDP, VIN, $\gamma \mathrm{HCH}$, and ATZ). The $100 \%$ value represents the value obtained in the presence of $1 \mathrm{nM} \mathrm{E}_{2}$. 


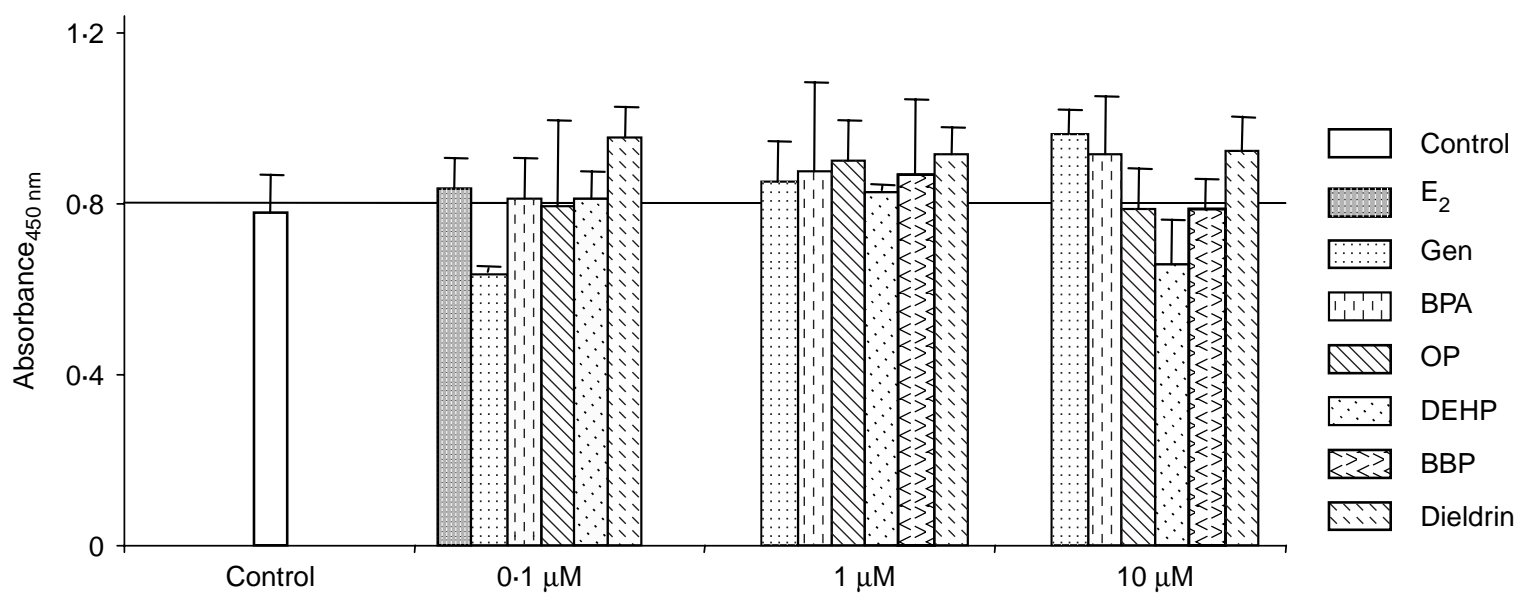

Figure 2 The effect of increasing concentrations of xenoestrogens on cell viability. MELN cells were seeded at a density of 5000 cells per well and treated for $24 \mathrm{~h}$ with vehicle or increasing concentrations of substances $(0 \cdot 1$ to $10 \mu \mathrm{M})$. Metabolic activity of viable cells was measured using XTT assay, as described in Materials and Methods. Data are represented by mean absorbance \pm s.D. This figure shows a representative result out of three independent experiments performed in triplicate. Cell viability assay indicated no toxicity effect of these compounds used at $10^{-5} \mathrm{M}$ and also at $10^{-4} \mathrm{M}$ for BBP (not shown).

than that observed with MELN (compare with Fig. 4A and B). No significant effect was observed with BPA in MELP (Fig. 4F). The increase of VEGF secretion with atrazine was variable between experiments in MELP, and not significant even at high concentration (Fig. $4 \mathrm{H}) . \gamma \mathrm{HCH}$, vinclozolin, and all the phthalates tested (DEHP, BBP, MBuP, DINP, and DIDP) were ineffective on VEGF secretion in this cell line (Figs. 4G, $\mathrm{H}$ and $5 \mathrm{~A}$ ).
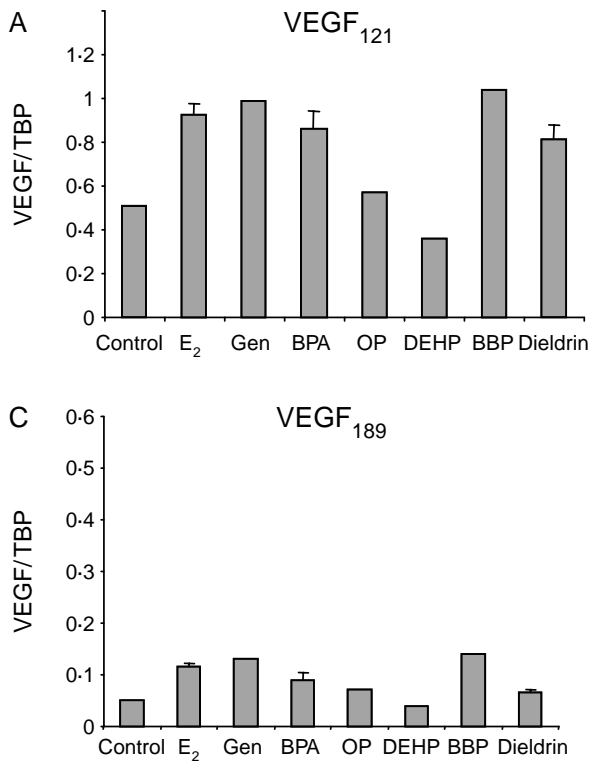

Altogether, these results indicate that genistein $\left(10^{-7} \mathrm{M}\right)$ and xenoestrogens $\left(10^{-6}\right.$ to $\left.10^{-5} \mathrm{M}\right)$, including BPA, OP, dieldrin, and, to a lesser extent DEHP and BBP, increased VEGF secretion in these breast cancer cells lines. They also indicate that MELN cells are more sensitive for the analysis of the effect of the chemical compounds on VEGF expression than MELP cells (with the exception of atrazine), similarly to the ERE-transactivation assay (Fig. 1).
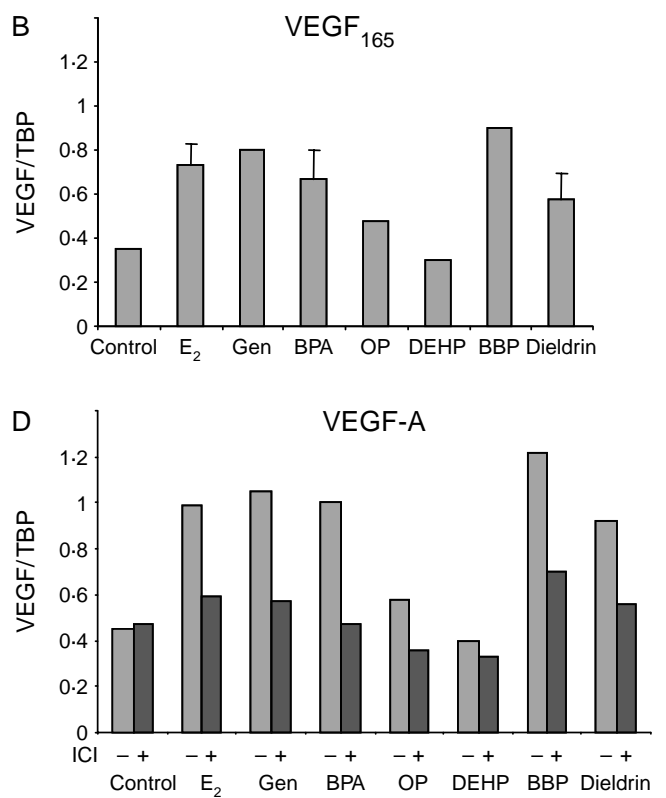

Figure 3 The effect of xenoestrogens on the expression level of VEGF transcripts. MELN cells were incubated for $6 \mathrm{~h}$ with ethanol, $1 \mathrm{nM}$ estradiol, $10 \mu \mathrm{M}$ genistein, $1 \mu \mathrm{M}$ bisphenol A, $10 \mu \mathrm{M}$ of OP, $100 \mu \mathrm{M}$ BBP, or $10 \mu \mathrm{M}$ dieldrin alone or in combination with $1 \mu \mathrm{M}$ of pure antiestrogen ICI 182 780. Quantitative RT-PCR analysis was performed on $1 \mu \mathrm{g}$ RNA, as described in Materials and Methods. Results are expressed as the ratio of VEGF $\operatorname{VE}_{121}(\mathrm{~A}), \mathrm{VEGF}_{165}(\mathrm{~B}), \mathrm{VEGF}_{189}(\mathrm{C})$, and VEGF-A in the presence of ICI (D)/TBP transcripts copies. Data are expressed as mean \pm s.D. of two independent experiments. 

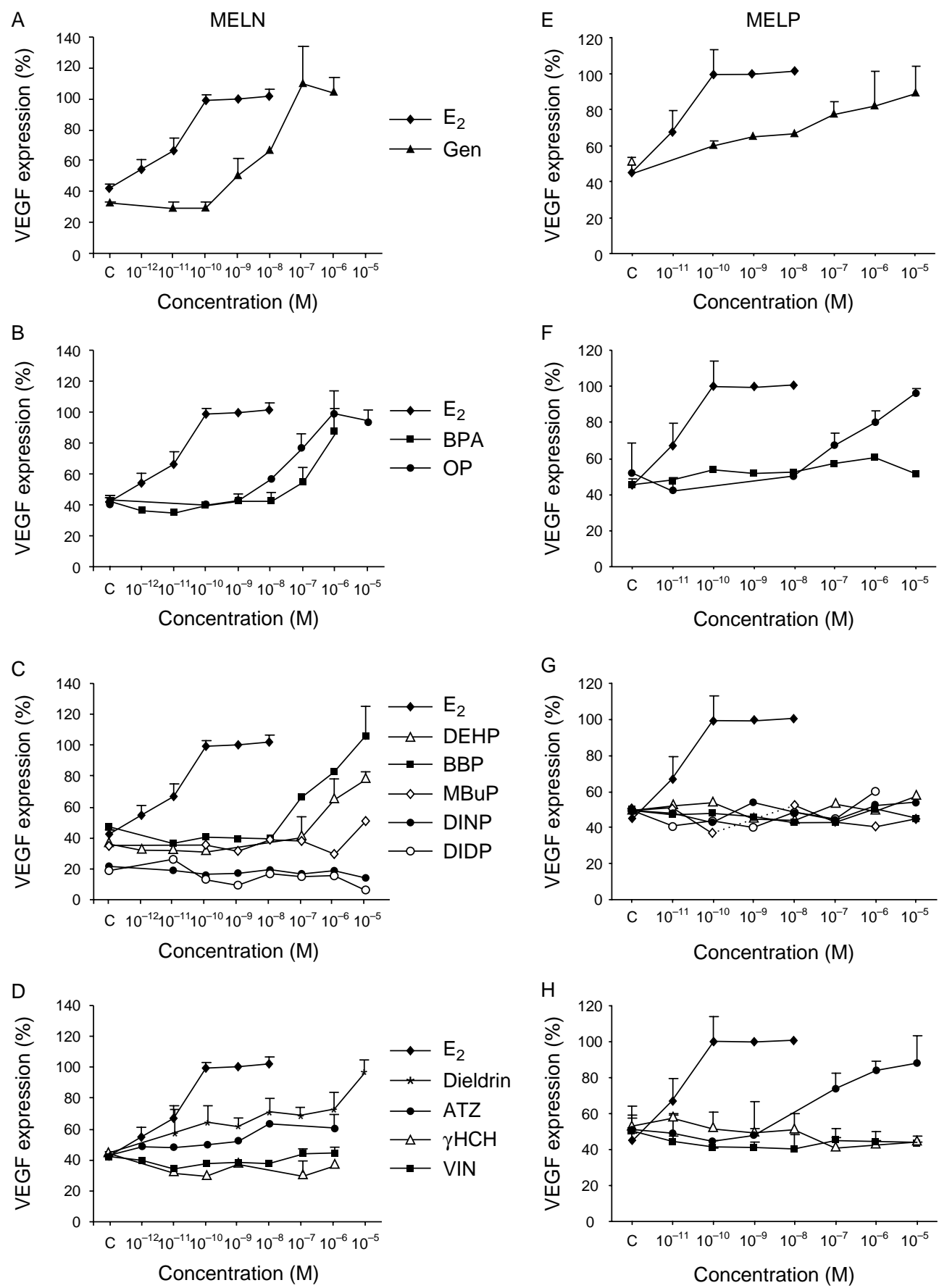

Figure 4 The effect of different environmental chemicals on VEGF protein expression in MELN and MELP cell lines. Cells were treated for $24 \mathrm{~h}$ with vehicle (ethanol or DMSO) and increasing concentrations of estradiol ( $\left.\mathrm{E}_{2}\right)$, genistein (Gen) (A and $\left.\mathrm{E}\right)$, bisphenol A (BPA), 4-(tertoctyl)phenol (OP) (B and F), di-ethyl-2-hexyle phthalate (DEHP), benzyl butyl phthalate (BBP), mono- $n$-butyl ester phthalic acid (MBuP), di-isononyle phthalate (DINP), di-isodecyle phthalate (DIDP) (C and G), dieldrin, lindane $(\gamma \mathrm{HCH})$, vinclozolin (VIN), or atrazine (ATZ) (D and $\mathrm{H}$ ). This time was shown to be optimal from previous kinetics experiments using $\mathrm{E}_{2}$ stimulation (Buteau-Lozano et al. 2002). Results are expressed as percentages of VEGF expression (mean \pm s.E.M. from at least three separate experiments performed in triplicates; mean \pm s.D. from a representative experiment performed in triplicates is shown for DINP, DIDP, VIN, $\gamma \mathrm{HCH}$, and ATZ). The $100 \%$ value represents the value obtained in the presence of $1 \mathrm{nM} \mathrm{E}_{2}$. 
A

MELN cell line
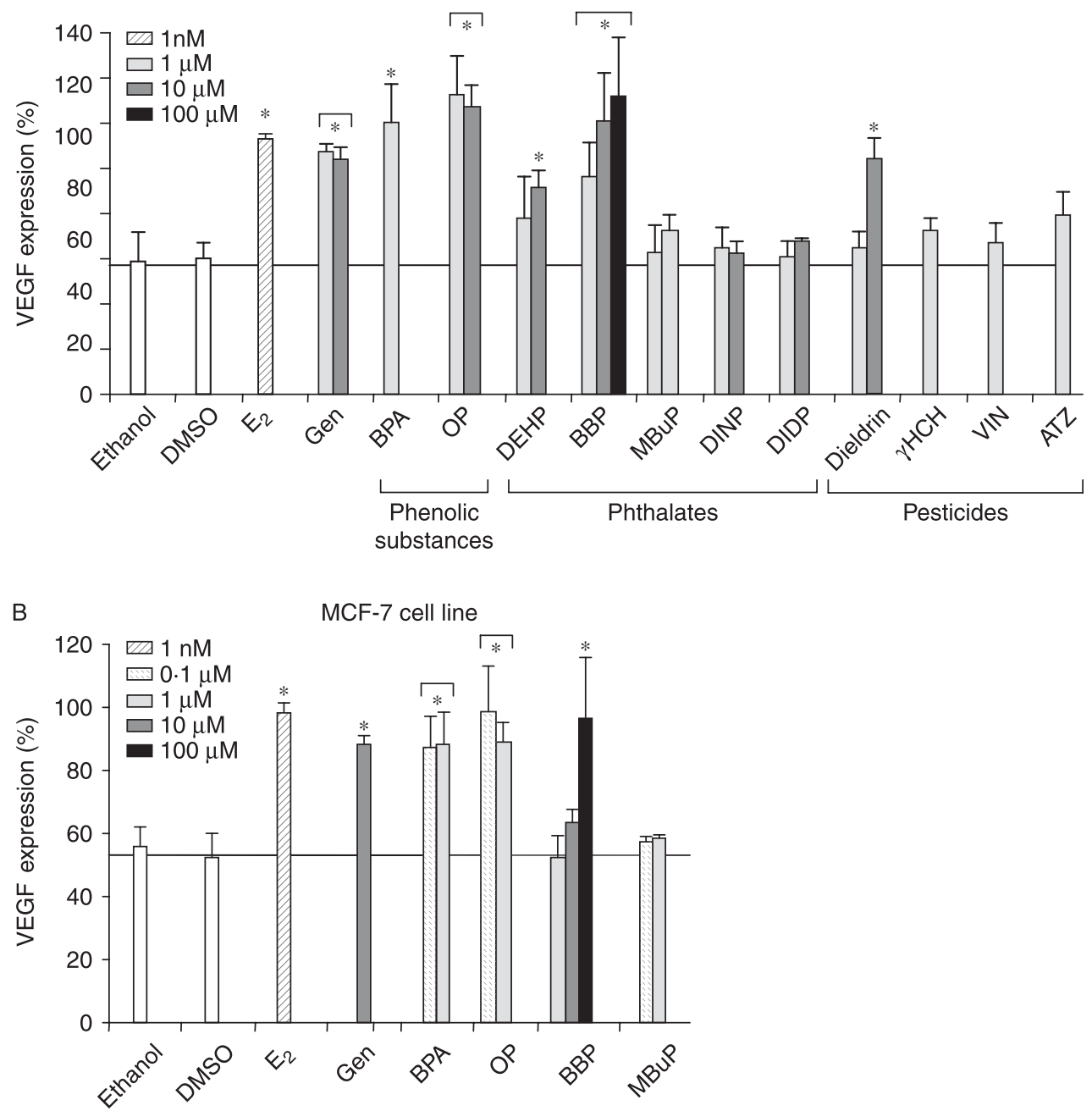

Figure 5 The effect of xenobiotics on VEGF protein expression in the stable MELN and parental MCF-7 cell lines. (A) MELN cells were treated for $24 \mathrm{~h}$ with vehicle (ethanol or DMSO), $\mathrm{E}_{2}$, and various concentrations of genistein (Gen), bisphenol A (BPA), 4-(tert-octyl)phenol (OP), di-ethyl-2-hexyle phthalate (DEHP), benzyl butyl phthalate (BBP), mono- $n$-butyl ester phthalic acid (MBuP), di-isononyle phthalate (DINP), di-isodecyle phthalate (DIDP), dieldrin, $\gamma \mathrm{HCH}$, vinclozolin (VIN), or atrazine (ATZ). Results are expressed as percentages of VEGF expression (mean \pm s.E.M. from at least three separate experiments performed in triplicates, except for ATZ (two different experiments)). The $100 \%$ value represents the value obtained in the presence of $1 \mathrm{nME}_{2}$. (B) MCF-7 cells were treated for $24 \mathrm{~h}$ with vehicle (ethanol or DMSO), $\mathrm{E}_{2}$, and various concentrations of genistein, $\mathrm{BPA}, \mathrm{OP}, \mathrm{BBP}$, and MBuP. Data (mean \pm s.D.) are values of three different experiments except for BPA (two different experiments; $* P<0 \cdot 05$ ).

Increase of VEGF expression by genistein and xenobiotics in breast cancer cell lines is ER dependent

Next, we determined whether VEGF increase was dependent on the presence of ER, using two different approaches, either breast cancer cells devoid or not of ER $\alpha$ or the pure antagonist ICI 182780.

We first compared VEGF expression in breast cancer cells MELN and the parental MCF-7 cells, both expressing endogenous ER $\alpha$ (Fig. 5A and B). Significant increase in VEGF secretion was observed in both cells stimulated by genistein, BPA, OP, and BBP. In MCF-7 cells (Fig. 5B), significant increase of VEGF secretion was observed with $\mathrm{E}_{2}$ $\left(1 \cdot 8\right.$-fold induction at $\left.10^{-9} \mathrm{M}\right)$, genistein $(1 \cdot 7$-fold induction at $\left.10^{-5} \mathrm{M}\right)$, OP $\left(1 \cdot 9\right.$-fold induction at $\left.10^{-7} \mathrm{M}\right)$, BPA $(1 \cdot 6$-fold induction at $\left.10^{-6} \mathrm{M}\right)$, and $\mathrm{BBP}\left(1 \cdot 8\right.$-fold induction at $10^{-4} \mathrm{M}$, Fig. 5B). We also compared VEGF expression in MELP and the parental MDA-MB-231 cells (Fig. 6). In contrast to MELP cell line which overexpress $\mathrm{ER} \alpha$, we could not detect any expression of $\mathrm{ER} \alpha$ or $\mathrm{ER} \beta$ in MDA-MB-231 cells (not shown). While $\mathrm{E}_{2}$, genistein, and $\mathrm{OP}$ increased VEGF secretion in MELP (Fig. 6A), no induction of VEGF expression by these substances was observed in parental MDA-MB-231 cells (Fig. 6B), suggesting that $\mathrm{ER} \alpha$ is necessary for VEGF stimulation.

We then examined the effect of the specific antiestrogen ICI 182 780, which has been shown to block $\mathrm{E}_{2}$-generated 

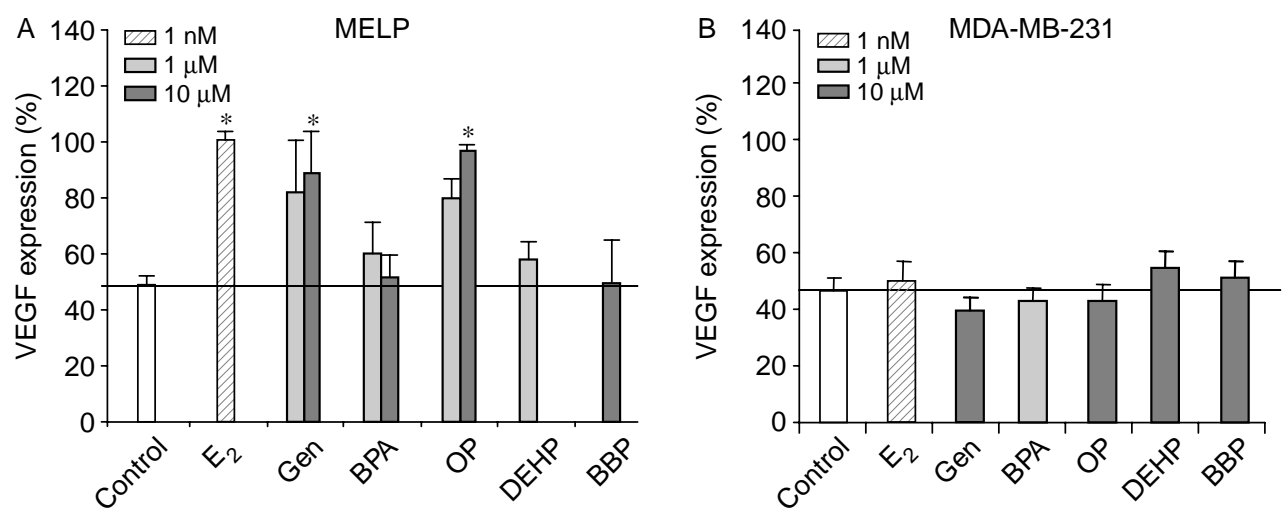

Figure 6 Comparison of the effect of xenobiotics on VEGF protein expression in the stable MELP and parental MDA-MB-231 cell lines. MELP (A) and parental MDA-MB-231 cells (B) were incubated for $24 \mathrm{~h}$ with ethanol, $1 \mathrm{nM} \mathrm{E}_{2}, 10 \mu \mathrm{M}$ genistein (Gen), $1 \mu \mathrm{M}$ bisphenol A (BPA), $10 \mu \mathrm{M}$ 4-(tert-octyl)phenol (OP), dieldrin, di-ethyl-2-hexyle phthalate (DEHP), and $100 \mu \mathrm{M}$ benzyl butyl phthalate (BBP). Results are expressed as percentages of VEGF expression (mean \pm S.E.M. from three separate experiments performed in triplicates). The $100 \%$ value represents the value obtained in the presence of $1 \mathrm{nM} \mathrm{E} \mathrm{E}_{2}$ for $24 \mathrm{~h}\left({ }^{*} P<0 \cdot 05\right)$.

transactivation and VEGF expression in breast cancer cells. As shown in Fig. 7, significant inhibition of VEGF increase in MELN was observed after addition of ICI 182780 in the presence of $\mathrm{E}_{2}$, genistein, BPA, OP, and dieldrin. The inhibition of the ERE-driven luciferase activity (data not shown, Balaguer et al. 2001) and of VEGF transcripts (see Fig. 3D) was observed in parallel in the cells stimulated with the different compounds in the presence of ICI 182780. Altogether, these results indicate that the increase of VEGF expression induced by high, non-cytotoxic, concentrations of xenoestrogens in breast cancer cell lines is ER dependent.

Xenoestrogens stimulate VEGF expression via multiple kinases pathways

The mechanism of action of structurally diverse xenoestrogens for VEGF activation is unknown and may be complex. Preliminary data from our laboratory indicate that BPA and OP increase VEGF transcription in MCF-7 and ER $\alpha-$ transfected MDA-MB-231 cells (data not shown), through complex mechanisms involving interaction of ER with VEGF promoter sequences, as already described for $E_{2}$ (Buteau-Lozano et al. 2002). Recently, alternative signaling pathways, such as the mitogen-activated protein kinase, the p38 kinase, and phosphatidylinositol-3-kinase (PI3-K), have also been implicated in ER-mediated VEGF regulation (Kazi et al. 2005, Yen et al. 2005).

To investigate if these kinase signaling pathways are implicated in the xenoestrogen-induced VEGF response, MELN cells were treated with PD98059 (MEK inhibitor), SB203580 (p38 kinase inhibitor), LY294002, and wortmaninn (PI3-K/Akt inhibitors) in the presence of compounds $(1-10 \mu \mathrm{M})$. As shown in Fig. 8, VEGF secretion induced by $E_{2}$, genistein, $\mathrm{OP}$, dieldrin, and $\mathrm{BBP}$ was greatly reduced by PD98059, suggesting involvement of a common MEK signaling pathway by these substances. The inhibitor
SB203580 decreased VEGF expression induced by genistein, $\mathrm{OP}$, dieldrin, and BBP, but to a lesser extent than MEK inhibitor; the SB203580 inhibitor was less efficient for the $\mathrm{E}_{2}$ response, suggesting different involvement of p38 kinase pathway in estrogenic compounds-stimulated VEGF expression (Fig. 8). Two different inhibitors of the PI3-K/ Akt pathway (LY294002 and wortmaninn), which is known as downstream effector of growth factor signaling, partially and similarly inhibited the VEGF expression induced by OP,

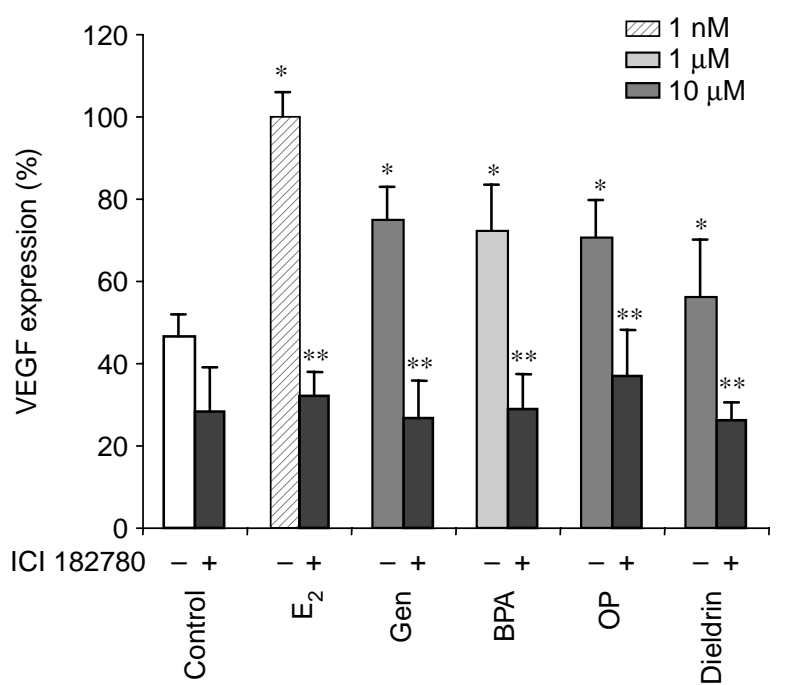

Figure 7 VEGF expression increase induced by xenobiotics is decreased by ICI 182780 in breast cancer cells. MELN cells were incubated for $24 \mathrm{~h}$ with ethanol, $1 \mathrm{nM} \mathrm{E}_{2}, 10 \mu \mathrm{M}$ genistein (Gen), $1 \mu \mathrm{M}$ bisphenol $\mathrm{A}$ (BPA), $10 \mu \mathrm{M}$ of 4-(tert-octyl)phenol (OP), and dieldrin alone or in combination with $1 \mu \mathrm{M}$ of pure antiestrogen $\mathrm{ICI}$ 182 780. Results are expressed as percentages of VEGF expression (mean \pm S.E.M. from three separate experiments performed in triplicates). The $100 \%$ value represents the value obtained in the presence of $1 \mathrm{nM} \mathrm{E}_{2}$ for $24 \mathrm{~h}\left({ }^{*} \mathrm{P}<0 \cdot 05\right)$. 
dieldrin, and BBP (Fig. 8). These results suggest that common and different kinase signaling pathways appear to be involved in $\mathrm{E}_{2}$ and xenoestrogen-induced VEGF response in mammary MELN cells.

\section{Discussion}

In this study, we show for the first time that xenoestrogens significantly increase VEGF expression in MELN derived from MCF-7 breast cancer cells. This is of particular interest because of the crucial role of VEGF in angiogenesis/vascular permeability and in cancer progression. These substances (BPA, OP, the pesticide dieldrin, and some phthalates including BBP and DEHP) are active on VEGF secretion and on ER transactivation assay at high, non-cytotoxic concentrations as deduced from results obtained in stable cell lines expressing ER $\alpha$ and EREluciferase gene and in MCF-7 cells. VEGF increase is not observed in stimulated MDA-MB-231 cells devoid of ER, and is abolished in MELN cells by the use of the pure antagonist ICI 182780 , at the protein and transcriptional level, suggesting that VEGF induction is mediated through an ER-dependent pathway in these cells.

$\mathrm{E}_{2}$ and genistein significantly increase VEGF expression in MELN and MELP cell lines in a dose-dependent manner. The increase of VEGF transcripts and protein was previously observed with $\mathrm{E}_{2}$ in MCF-7 cells (Ruohola et al. 1999, Buteau-Lozano et al. 2002, Garvin \& Dabrosin 2003) or ZR75 cells (Stoner et al. 2004). MELN cell line appears more sensitive than MELP regarding both ERE mediation and VEGF expression. The lower sensitivity in MELP could be due to the lower ER $\alpha$ concentration (see Materials and Methods), cell context and differential expression of nuclear factors between cell lines, or be correlated to the introduction of ER in cells which are initially devoid of the receptor. In addition, $E_{2}$ and genistein do not increase VEGF expression in cells devoid of functional receptor, unless ER was transfected (Buteau-Lozano et al. 2002); the inhibition of VEGF increase (both transcript and protein) by ICI also suggests that VEGF induction is mediated through an ER-dependent pathway.

Our in vitro results also indicate the induction of VEGF expression in MELN stimulated with high concentrations of different xenoestrogens, including BPA and OP, dieldrin, BBP, and DEHP. The absence of a plateau in the observed VEGF responses (with BPA, BBP, DEHP, and dieldrin) could be due to the low affinity of these compounds to the nuclear ER. Also, a higher sensitivity observed in MELN appears more sensitive to MELP, as mentioned for $E_{2}$ and genistein. BPA and OP have previously been identified as endocrine disruptors in several in vivo models, and induce alterations of the normal rodent sexual development. BPA is a diphenylalkane, which is extensively used in the manufacture of polycarbonate plastics and epoxyresins in cans (Brotons et al. 1995); OP may be present in food as a decomposition product from alkylphenol ethoxylates and is used in food contact plastics (Fernandes et al. 2003). Our results show that BPA and $\mathrm{OP}$ at $10^{-6} \mathrm{M}$ increase VEGF secretion in MCF-7 and MELN cells. This increase is correlated to their estrogenic activity in MELN, consistent with previous studies performed in MCF-7 and MELN (Soto et al. 1995, Andersen et al. 1999, Paris et al. 2002).

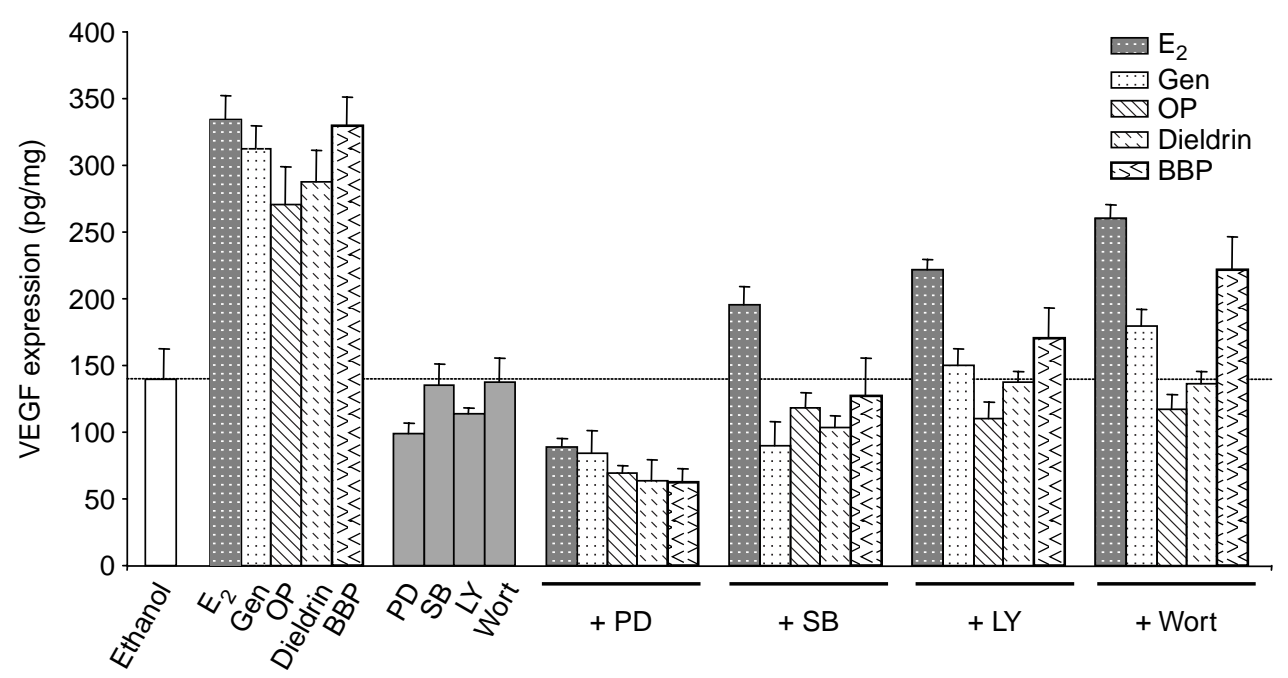

Figure 8 Multiple protein kinase pathways involved in $E_{2}$ and xenoestrogens-induced VEGF expression. MELN cells were pre-treated with various kinase signaling inhibitors $(20 \mu \mathrm{M}$ PD98059, $10 \mu \mathrm{M}$ SB203580, $25 \mu \mathrm{M}$ LY294002, or 0.1 $\mu \mathrm{M}$ wortmaninn) for a period of $2 \mathrm{~h}$ after which they were exposed to $E_{2}(1 \mathrm{nM})$, BPA $(1 \mu \mathrm{M})$, OCP $(10 \mu \mathrm{M})$, genistein $(10 \mu \mathrm{M})$, dieldrin $(10 \mu \mathrm{M})$, and BBP $(100 \mu \mathrm{M})$ for a further $24 \mathrm{~h}$. VEGF expression (pg/mg) was determined by immunoassay as described in Materials and Methods. Results are representative of three independent experiments performed in triplicates. 
Phthalates are used in plastics and other common consumer products. Given their high-production volume and widespread environmental contamination, humans are daily exposed to these compounds through ingestion, inhalation, and dermal contact. Exposure to BBP, DEHP, or DBP may result in irreversible changes in the development of the male reproductive tract, impairment of uterine function, and increased risk of skin and liver tumors (Fisher et al. 2003). We show that, among phthalates, BBP, and DEHP significantly increase VEGF expression in MELN. BBP is the most active compound and the induction level of VEGF at $10^{-4} \mathrm{M}$ is similar to that observed with $1 \mathrm{nM} \mathrm{E}_{2}$. BBP and DEHP are considered as weak xenoestrogens in vitro, using MCF-7 proliferation test or the yeast model (Jobling et al. 1995, Soto et al. 1995, Andersen et al. 1999, Picard et al. 2001, Okubo et al. 2003), in agreement with this study.

Among the pesticides and fungicides that we have analyzed, dieldrin significantly increases VEGF expression in MELN cells. Dieldrin is a persistent organochlorine pesticide which was banned in most countries several years ago, due to its bioaccumulative properties and negative impact on wildlife reproduction. This pesticide has also estrogenic activity in the ERE-luciferase assay, in agreement with other studies (Soto et al. 1995, Andersen et al. 2002). In contrast, $\gamma \mathrm{HCH}$ (an organochloride insecticide), vinclozolin (a fungicide used in wine industry), and atrazine were ineffective on VEGF secretion, a finding which correlates to their absence of estrogenic activity (Soto et al. 1995, Connor et al. 1996, and this study). Further studies will analyze the possible effect of $\beta-\mathrm{HCH}$ isomer, which exerts estrogen-like effects in MCF-7 cells and in vivo (Steinmetz et al. 1996), on VEGF expression. Vinclozolin is considered as an androgen receptor antagonist that inhibits androgen-dependent tissue growth in vivo (Kelce et al. 1997). In our study, the absence of induction of vinclozolin on VEGF expression appears to correlate with the absence of estrogenic activity. Further studies will analyze the possible effect of this pesticide on VEGF expression in an androgen-dependent cell line.

The xenoestrogens used in this study are fairly weak estrogens and increase VEGF expression in MELN cells, when applied at $0 \cdot 1-10 \mu \mathrm{M}$, in agreement with their significant estrogenic activity when present in very large quantity. In vivo, BPA increases VEGF expression in the immature rat uterus $(37 \mathrm{mg} / \mathrm{kg}$ being the lowest active dose; Long et al. 2001); genistein, BPA, OP, and BBP have also been shown to increase uterine vascular permeability in ovariectomized mice (Milligan et al. 1998); no evidence of any significant synergy or antagonism between the compounds were observed (Milligan et al. 1998), in agreement with our data showing that low doses of xenoestrogens (i.e., below the level required to induce an estrogenic response) were ineffective in combination with a stimulatory dose of $E_{2}$ (not shown).

The molecular mechanism of VEGF regulation by xenoestrogens in breast cancer cells appears to be complex. Arguments that VEGF responses are mainly ER dependent in
MELN cells come from experiments showing that i) the effect is only observed in breast cancer cells which express $\mathrm{ER} \alpha$ (it is not observed in MDA-MB-231 which do not express ER) and ii) the effect is blocked by co-treatment with a pure antiestrogen. The finding that xenoestrogens induce VEGF transcript levels (Fig. 3D) suggests a genomic effect. A good correlation of these compounds in modulation of VEGF expression and their estrogenic property using the ERE transactivation assay is also observed in MELN cells. We are currently analyzing promoter region of VEGF gene involved in VEGF activation by these compounds using transfection experiments. VEGF promoter is complex with multiple consensus sequences for different transcription factors (Tischer et al. 1991). Attempts to identify the sites through which ERs act to induce VEGF expression have involved an ERE (Hyder et al. 2000, Mueller et al. 2000, Buteau-Lozano et al. 2002), or interaction of ER with other transcription factors such SP1/3 sites (Stoner et al. 2004) and the hypoxiaresponsive element (Kazi et al. 2005), or through activation of kinase cascade pathways (Yen et al. 2005), depending on the nature of cells and the microenvironment including hypoxia/ normoxia, the estrogenic medium and differential expression of other nuclear factors. Preliminary experiments indicate that BPA, OP, dieldrin, and BBP do not increase VEGF induction in hypoxia conditions in MELN (high levels of HIF-1 $\alpha$ (personal data)). Our experiments with protein kinase inhibitors (MEK/ERK1/2, p38 kinase, and PI3-K/Akt pathways) also suggest for the first time that xenoestrogens induce the VEGF response in MELN cells via specific kinase pathways. These kinase pathways have previously been shown to play a role in regulating VEGF expression in response to growth factors (Maity et al. 2000, Milanini-Mongiat et al. 2002), diosgenin (Yen et al. 2005), and androgens (Mabjeesh et al. 2003), in agreement with this study. In addition, non-genomic actions for $\mathrm{E}_{2}$ or xenoestrogens at low concentrations through the rapid activation of signal cascade emanating from the membrane have also been described (Nadal et al. 2000, Zivadinovic \& Watson 2005). However, although low doses of xenoestrogens exhibit a physiological effect (rapidly phosphorylate ERK1/2) in MELN cells (data not shown), we have no evidence that these low concentrations increase VEGF expression in MELN cells.

While xenoestrogens are mainly estrogenic, some of these same chemicals may be able to bind with different receptors at $\mu \mathrm{M}$ concentrations, like the androgen receptor (as for BPA, $\mathrm{OP}$, and dieldrin acting as anti-androgens; Andersen et al. 2002, Paris et al. 2002, Lemaire et al. 2004), or to bind to PXR (phthalates and alkylphenols; Mnif et al. 2007), RAR (pesticides; Lemaire et al. 2005), or interfere with steroid hormone synthesis or metabolism (dieldrin; Lemaire et al. 2004) by PXR activation. Modulation of VEGF secretion in cells which express these receptors is thus not excluded.

The in vivo potency of xenoestrogens depends on a number of factors, including their number (additive or synergistic effects), dose and nature of xenoestrogen, route and the period of administration, the monitored response, and 
the bioaccumulation in (or release from) tissues. Prenatal exposure to endocrine disruptors, including BPA, can alter the development of the mouse mammary gland (Brown et al. 1998, Markey et al. 2001, Birnbaum \& Fenton 2003, Maffini et al. 2006) and the susceptibility to further carcinogenic exposure in the adult. Recently, perinatal exposure to low doses of BPA was shown to increase estrogen sensitivity of the rodent mammary gland (Vanderberg et al. 2007). The experimental and epidemiological studies have also suggested that dieldrin, $\beta-\mathrm{HCH}$, atrazine, and dioxins, can enhance mammary carcinogenesis (Steinmetz et al. 1996, Birnbaum \& Fenton 2003, Fukamachi et al. 2004, Mitra et al. 2004). In addition, organochlorines (such as dieldrin and $\beta-\mathrm{HCH}$ ) are lipophylic molecules that accumulate in fat stores (including breast fat), and several studies have described that, during periods of dietary restriction, they can be released in quantities sufficient to stimulate estrogen target tissues in animal studies (fast-induced lipolysis; Zabik \& Schemmel 1973, Bigsby et al. 1997, Penza et al. 2004). A strong association has been described between the incidence of breast cancer and levels of lipophylic xenoestrogens present in breast adipose tissue (Steinmetz et al. 1996, Starek 2003, Ibarluzea et al. 2004). Recently, a new approach of biomonitoring exposure to environmental estrogens in breast cancer (Fernandez et al. 2007) could permit retrospective studies to be performed on breast cancer.

In summary, we described for the first time the modulation of VEGF by xenoestrogens in breast cancer cells, in correlation with their estrogenic activity. VEGF is a stimulator of angiogenesis/vascular permeability in vivo and acts as an autocrine growth factor for mammary cancer cells (Schoeffner et al. 2005, Herve et al. 2008). Whether a class of xenoestrogen may play a role in angiogenesis/vascular permeability and in the pathogenesis of estrogen-responsive cancer remains to be examined in detail. The possible effects of xenoestrogens at low doses, which are within the range of environmentally relevant doses, on VEGF expression and angiogenesis need also to be explored in different in vitro and in vivo models.

\section{Acknowledgements}

The authors are grateful to J Desarnauts and J F Regnier (Arkema), Dr Wakeling for the gift of ICI 182 780, Dr F Petit (INSERM U553) for helpful discussions, Dr C Legrand (U553), E Savariau for infography services (Institut Universitaire d'Hématologie, Hôpital Saint Louis, Paris, France), and $\mathrm{N}$ Sommay for his technical assistance. This work was supported by INSERM, the Ligue contre le Cancer, with funding provided by Arkema (La Défense, Neuilly, France). Partially presented in International workshop on endocrine active substances, Yokohama (Japan) 2001. The authors declare that there is no conflict of interest that would prejudice the impartiality of this scientific work.

\section{References}

Ancelin M, Buteau-Lozano H, Meduri G, Osborne-Pellegrin M, Sordello S, Plouet J \& Perrot-Applanat M 2002 A dynamic shift of VEGF isoforms with a transient and selective progesterone-induced expression of VEGF189 regulates angiogenesis and vascular permeability in human uterus. PNAS $996023-6028$

Andersen HR, Andersson AM, Arnold SF, Autrup H, Barfoed M, Beresford NA, Bjerregaard P, Christiansen LB, Gissel B, Hummel R et al. 1999 Comparison of short-term estrogenicity tests for identification of hormone-disrupting chemicals. Environmental Health Perspectives 107 89-108.

Andersen HR, Vinggaard AM, Rasmussen TH, Gjermandsen IM \& Bonefeld-Jorgensen EC 2002 Effects of currently used pesticides in assays for estrogenicity, androgenicity, and aromatase activity in vitro. Toxicology and Applied Pharmacology 179 1-12.

Balaguer P, Francois F, Comunale F, Fenet H, Boussioux AM, Pons M, Nicolas JC \& Casellas C 1999 Reporter cell lines to study the estrogenic effects of xenoestrogens. Science of the Total Environment 233 47-56.

Balaguer P, Boussioux AM, Demirpence E \& Nicolas JC 2001 Reporter cell lines are useful tools for monitoring biological activity of nuclear receptor ligands. Luminescence 16 153-158.

Bausero P, Cavaillé F, Meduri G, Freitas S \& Perrot-Applanat M 1998 Paracrine action of vascular endothelial growth factor in the human endometrium: production and target sites, and hormonal regulation. Angiogenesis 2 167-182.

Bieche I, Tozlu S, Girault I, Onody P, Driouch K, Vidaud M \& Lidereau R 2004 Expression of PEA3/E1AF/ETV4, an Ets-related transcription factor, in breast tumors: positive links to MMP2, NRG1 and CGB expression. Carcinogenesis 25 405-411.

Bigsby RM, Caperell-Grant A \& Madhukar BV 1997 Xenobiotics released from fat during fasting produce estrogenic effects in ovariectomized mice. Cancer Research 57 865-869.

Birnbaum L \& Fenton SE 2003 Cancer and developmental exposure to endocrine disruptors. Environmental Health Perspectives 111 389-394.

Brotons JA, Olea-Serrano MF, Villalobos M, Pedraza V \& Olea N 1995 Xenoestrogens released from lacquer coatings in food cans. Environmental Health Perspectives 103 608-612.

Brown NM, Manzolillo PA, Zhang JX, Wang J \& Lamartinière CA 1998 Prenatal TCDD and predisposition to mammary cancer in the rat. Carcinogenesis 19 1623-1629.

Buteau-Lozano H, Ancelin M, Lardeux B, Milanini J \& Perrot-Applanat M 2002 Transcriptional regulation of vascular endothelial growth factor by estradiol and tamoxifen in breast cancer cells: a complex interplay between estrogen receptors $\alpha$ and $\beta$. Cancer Research 62 4977-4984.

Carson-Jurica MA, Schrader WT \& O'Malley BW 1990 Steroid receptor family: structure and functions. Endocrine Reviews 11 201-220.

Colburn T 1995 Environmental estrogens: health implications for human and wildlife. Environmental Health Perspectives 103 135-136.

Connor K, Howell J, Chen I, Liu H, Berhane K, Sciarretta C, Safe S \& Zacharewski T 1996 Failure of chloro-S-triazine-derived compounds to induce estrogen receptor-mediated responses in vivo and in vitro. Fundamental and Applied Toxicology 30 93-101.

Cullinan-Bove K \& Koos RD 1993 Vascular endothelial growth factor/vascular permeability factor expression in the rat uterus: rapid stimulation by estrogen correlates with estrogen-induced increases in uterine capillary permeability and growth. Endocrinology 133 829-837.

Dabrosin C 2003 Variability of vascular endothelial growth factor in normal human breast tissue in vivo during the menstrual cycle. Journal of Clinical Endocrinology and Metabolism 88 2695-2698.

Dabrosin C, Margetts PJ \& Gauldie J 2003 Estradiol increases extracellular levels of vascular endothelial growth factor in vivo in murine mammary cancer. International Journal of Cancer 107 535-540.

Diel P, Olff S, Schmidt S \& Michna H 2002 Effects of the environmental estrogens bisphenol A, o, $\mathrm{p}^{\prime}$-DDT, $p$-ter-octylphenol and coumestrol on apoptosis induction, cell proliferation and the expression of estrogen sensitive molecular parameters in the human breast cancer cell line MCF-7. Journal of Steroid Biochemistry 80 61-70. 
Fernandes AR, Costley CT \& Rose M 2003 Determination of 4-octylphenol and 4-nonylphenol congeners in composite foods. Food Additives and Contaminants 20 846-852.

Fernandez MF, Santa-Marina L, Ibarluzea JM, Exposito J, Aurrekoetxea JJ, Torne P, Laguna J, Rueda AI, Pedraza V \& Olea N 2007 Analysis of population characteristics related to the total effective xenoestrogen burden: a biomarker of xenoestrogen exposure in breast cancer. European Journal of Cancer 43 1290-1299.

Ferrara N \& Davis-Smith T 1997 The biology of vascular endothelial growth factor. Endocrine Reviews 18 4-25.

Fisher JS, Macpherson S, Marchetti N \& Sharpe RM 2003 Human testicular syndromes: a possible model based on in utero exposure of the rat to dibutyl phthalate. Human Reproduction 7 1383-1394.

Fukamachi K, Han BS, Kim CK, Takasuka N, Matsuoka Y, Matsuda E, Yamasaki T \& Tsuda H 2004 Possible enhancing effects of atrazine and nonylphenol on 7,12-dimethylbenz[a]anthracene-induced mammary tumor development in human c-Ha-ras proto-oncogene transgenic rats. Cancer Science 95 404-410.

Garvin S \& Dabrosin C 2003 Tamoxifen inhibits secretion of vascular endothelial growth factor in breast cancer in vivo. Cancer Research 63 8742-8748.

Hall JM \& Korach KS 2002 Analysis of the molecular mechanisms of human estrogen receptors alpha and beta reveals differential specificity in target promoter regulation by xenoestrogens. Journal of Biological Chemistry 277 44455-44461.

Herve M-A, Buteau-Lozano H, Mourah S, Calvo F \& Perrot-Applanat M 2005 VEGF189 stimulates endothelial cells proliferation and migration in vitro and up-regulates the expression of Flk-1/KDR mRNA. Experimental Cell Research 309 24-31.

Herve M-A, Buteau-Lozano H, Vassy R, Bieche I, Pla M, Perret G, Mourah S \& Perrot-Applanat M 2008. Overexpression of VEGF189 in breast cancer cells leads to delayed tumor uptake with dilated intratumoral vessels. American Journal of Pathology 172 1-12.

Hopenhayn-Rich C, Stump ML \& Browning SR 2002 Regional assessment of atrazine exposure and incidence of breast and ovarian cancers in Kentucky. Archives of Environmental Contamination and Toxicology 42 127-136.

Hoyer AP, Grandjean P, Jorgensen T, Brock JW \& Hartvig HB 1998 Organochlorine exposure and risk of breast cancer. Lancet 352 1816-1820.

Hyder SM, Murthy L \& Stancel GM 1998 Progestin regulation of vascular endothelial growth factor in human breast cancer cells. Cancer Research $\mathbf{5 8}$ 392-395.

Hyder SM, Nawaz Z, Chiappetta C \& Stancel GM 2000 Identification of functional estrogen response elements in the gene coding for the potent angiogenic vascular endothelial growth factor. Cancer Research 60 3183-3190.

Ibarluzea JM, Fernandez MF, Santa-Marina L, Olea-Serrano MF, Rivas AM, Aurrekoetxea JJ, Exposito J, Lorenzo M, Torne P, Villalobos M et al. 2004 Breast cancer risk and the combined effect of environmental estrogens. Cancer Causes and Control 15 591-600.

Jobling S, Reynolds T, White R, Parker MG \& Sumpter JP 1995 A variety of environmentally persistent chemicals, including some phthalate plasticizers, are weakly estrogenic. Environmental Health Perspectives 103 582-587.

Jordan VC \& Murphy CS 1990 Endocrine pharmacology of antiestrogens as antitumor agents. Endocrine Reviews 11 578-610.

Kazi AA, Jones JM \& Koos RD 2005 Chromatin immunoprecipitation analysis of gene expression in the rat uterus in vivo: estrogen-induced recruitment of both estrogen receptor alpha and hypoxia-inducible factor 1 to the vascular endothelial growth factor promoter. Molecular Endocrinology 19 2006-2019.

Kelce WR, Lambright CR, Gray LE, Jr \& Roberts KP 1997 Vinclozolin and $p, p^{\prime}$-DDE alter androgen-dependent gene expression: in vivo confirmation of an androgen receptor-mediated mechanism. Toxicology and Applied Pharmacology 142 192-200.

Koopman-Esseboom C, Morse DC, Weisglas-Kuperus N, Lutkeschipholt IJ, Van der Paauw CG, Tuinstra LG, Brouwer A \& Sauer PJ 1994 Effects of dioxins and polychlorinated biphenyls on thyroid hormone status of pregnant women and their infants. Pediatric Research 36 468-473.
Kuiper GGJM, Carlson B, Grandien KAJ, Enmark E, Haggblad J, Nilsson S \& Gustafsson J-A 1997 Comparison of the ligand binding specificity and transcript tissue distribution of estrogen receptors $\alpha$ and $\beta$. Endocrinology 138 863-870.

Legler J, van den Brink CE, Brouwer A, Murk AJ, van der Saag P, Vethaak AD \& van der Burg B 1999 Development of a stably transfected estrogen receptor-mediated luciferase gene reporter assay in the human T47D breast cancer cell line. Toxicological Sciences 48 55-66.

Lemaire G, Terouanne B, Mauvais P, Michel S \& Rahmani R 2004 Effect of organochlorine pesticides on human androgen receptor activation in vitro. Toxicology and Applied Pharmacology 196 235-246.

Lemaire G, Balaguer P, Michel S \& Rahmani R 2005 Activation of retinoic acid receptor-dependent transcription by organochlorine pesticides. Toxicology and Applied Pharmacology 202 38-49.

Long X, Burke KA, Bigsby RM \& Nephew K 2001 Effects of the xenoestrogen bisphenol A on expression of vascular endothelial growth factor (VEGF) in the rat. Experimental Biology and Medicine 226 477-483.

Mabjeesh NJ, Willard MT, Frederickson CE, Zhong H \& Simons JW 2003 Androgens stimulate hypoxia-inducible factor 1 activation via autocrine loop of tyrosine kinase receptor/phosphatidylinositol $3^{\prime}$ kinase/protein kinase B in prostate cancer cells. Clinical Cancer Research 9 2416-2425.

Maffini MV, Rubin BS, Sonnenschein C \& Soto AM 2006 Endocrine disruptors and reproductive health: the case of bisphenol-A. Molecular and Cellular Endocrinology 254-255 179-186.

Maity A, Pore N, Lee J, Solomon D \& O'Rourke DM 2000 Epidermal growth factor receptor transcriptionally up-regulates vascular endothelial growth factor expression in human glioblastoma cells via a pathway involving phosphatidylinositol 3'-kinase and distinct from that induced by hypoxia. Cancer Research 60 5879-5886.

Markey CM, Luque EH, Munoz De Toro M, Sonnenschein C \& Soto AM 2001 In utero exposure to bisphenol A alters the development and tissue organization of the mouse mammary gland. Biology of Reproduction 65 1215-1223.

Milanini-Mongiat J, Poussegur J \& Pages G 2002 Identification of two Sp1 phosphorylation sites for $\mathrm{p} 42 / \mathrm{p} 44$ mitogen-activated protein kinases: their implication in vascular endothelial growth factor gene transcription. Journal of Biological Chemistry 277 20631-20639.

Milligan SR, Balasubramanian AV \& Kalita JC 1998 Relative potency of xenobiotic estrogens in an acute in vivo mammalian assay. Environmental Health Perspectives 106 23-26.

Mills PK 1998 Correlation analysis of pesticides use data and cancer incidence rates in California countries. Archives of Environmental Health 53 410-413.

Mitra A, Faruque FS \& Avis A 2004 Breast cancer and environmental risks: where is the link? Journal of Environmental Health 66 24-32.

Mnif W, Pascussi JM, Pillon A, Escande A, Bartegi A, Nicolas JC, Cavailles V, Duchesne MJ \& Balaguer P 2007 Estrogens and antiestrogens activate hPXR. Toxicology Letters 170 19-29.

Mueller MD, Vigne JL, Minchenko A, Lebovic DI, Leitman DC \& Taylor RN 2000 Regulation of vascular endothelial growth factor (VEGF) gene transcription by estrogen receptor $\alpha$ and $\beta$. PNAS 97 10972-10977.

Nadal A, Ropero AB, Laribi O, Maillet M, Fuentes E \& Soria B 2000 Non genomic actions of estrogens and xenoestrogens by binding at a plasma membrane receptor unrelated to estrogen receptor alpha and estrogen receptor beta. PNAS 97 11603-11608.

Nakamura J, Savinov A, Lu Q \& Brodie A 1996 Estrogen regulated vascular endothelial growth/permeability factor expression in 7,12-dimethylbenz(a)anthracene-induced rat mammary tumors. Endocrinology 137 5589-5596.

Okubo T, Suzuki T, Yokoyama Y, Kano K \& Kano I 2003 Estimation of estrogenic and anti-estrogenic activities of some phthalate diesters and monoesters by MCF-7 cell proliferation assay in vitro. Biological and Pharmaceutical Bulletin 26 1219-1224.

Olsen CM, Meussen-Elholm ET, Samuelsen M, Holme JA \& Hongslo JK 2003 Effects of the environmental oestrogens bisphenol A, tetrachlorobisphenol A, tetrabromobisphenol A, 4-hydroxybiphenyl and 4,4'-dihydroxybiphenyl on oestrogen receptor binding, cell proliferation and regulation of oestrogen sensitive proteins in the human breast cancer cell line MCF-7. Pharmacology and Toxicology 92 180-188. 
Paech K, Webb P, Kuiper GGJM, Nilsson S, Gustafsson J-A, Kushner PJ \& Scanlan TS 1997 Differential ligand activation of estrogen receptors ER $\alpha$ and ER $\beta$ at AP-1 sites. Science 277 1508-1510.

Paris F, Balaguer P, Térouanne B, Servant N, Lacoste C, Cravedi JP, Nicolas JC \& Sultan C 2002 Phenylphenols, bisphenols, bisphenol A and 4-teroctylphenol exhibit $\alpha$ and $\beta$ estrogen activities and anti-androgen activity in reporter cell lines. Molecular and Cellular Endocrinology 193 43-49.

Penza M, Bonetti E, Villa R, Ganzerla S, Bergonzi R, Biasiotto G, Caimi L, Apostoli P, Ciana P, Maggi A et al. 2004 Whole body action of xenoestrogens with different chemical structures in estrogen reporter male mice. Toxicology 205 65-73.

Picard K, Luguenot JC, Lavier-Canivenc MC \& Chagnon MC 2001 Estrogenic activity and metabolism of $\mathrm{N}$-butyl phthalate in vitro: identification of the active molecule(s). Toxicology and Applied Pharmacology 172 108-118.

Ruohola JK, Valve EM, Karkkainen MJ, Joukov V, Alitalo K \& Härkönen PL 1999 Vascular endothelial growth factors are differentially regulated by steroid hormones and antiestrogens in breast cancer cells. Molecular and Cellular Endocrinology 149 29-40.

Safe S 2005 Clinical correlates of environmental endocrine disruptors. Trends in Endocrinology and Metabolism 16 139-144.

Sasco A 2001 Epidemiology of breast cancer: an environmental disease? Acta Pathologica, Microbiologica. et Immunologica Scandinavica 109 321-332.

Schoeffner DJ, Matheny SL, Akahane T, Factor V, Berry A, Merlino G \& Thorgeirsson UP 2005 VEGF contributes to mammary tumor growth in transgenic mice through paracrine and autocrine mechanisms. Laboratory Investigation 85 608-623.

Sharpe RM \& Irvine DS 2004 How strong is the evidence of a link between environmental chemicals and adverse effects on human reproductive health? BMJ 328 447-451.

Shifren JL, Tseng J, Zaloudek C, Ryan IP, Meng YG, Ferrara N, Jaffa RB \& Taylor RN 1996 Ovarian steroid regulation of vascular endothelial growth factor in human endometrium: implications for angiogenesis during the menstrual cycle and in the pathogenesis of endometriosis. Journal of Clinical Endocrinology and Metabolism 81 3112-3118.

Sonnenschein C \& Soto AM 1998 An update review of environmental estrogen and androgen mimics and antagonists. Journal of Steroid Biochemistry and Molecular Biology 65 143-150.

Soto AM, Sonnenschein C, Chung KL, Fernandez MF, Olea N \& Serrano FO 1995 The E-SCREEN assay as a tool to identify estrogens: an update on estrogenic environmental pollutants. Environmental Health Perspectives 103 1113-1120.

Starek A 2003 Estrogens and organochlorine xenoestrogens and breast cancer risk. International Journal of Occupational Medicine and Environmental Health 16 113-124.
Stein B \& Yang MX 1995 Repression of the interleukin-6 promoter by estrogen receptor is mediated by NF- $\mathrm{KB}$ and $\mathrm{C} / \mathrm{EBP}$ beta. Molecular and Cellular Biology 15 4971-4979.

Steinmetz R, Young PCM, Caperell-Grant A, Gize EA, Madhukar BV, BenJonathan N \& Bigsby RM 1996 Novel estrogenic action of the pesticide residue beta-hexachlorocyclohexane in human breast cancer cells. Cancer Research 56 5403-5409.

Stoner M, Wormke M, Saville B, Samudio I, Qin C, Abdelrahim M \& Safe S 2004 Estrogen regulation of vascular endothelial growth factor expression in ZR-75 breast cancer cells through interaction of estrogen receptor $\alpha$ and SP proteins. Oncogene 23 1052-1063.

Teilmann G, Juul A, Skakkebaek NE \& Toppari J 2002 Putative effects of endocrine disrupters on pubertal development in the human. Best Practice and Research, Clinical Endocrinology and Metabolism 16 105-121.

Terasaka S, Aita Y, Inoue A, Hayashi S, Nishigaki M, Aoyagi K, Sasaki H, Wada-Kiyama Y, Sakuma Y, Akaba S et al. 2004 Using a customized DNA microarray for expression profiling of the estrogen-responsive genes to evaluate estrogen-activity among natural estrogens and industrial chemicals. Environmental Health Perspectives 112 773-781.

Tischer E, Mitchell R, Hartman T, Silva M, Gospodarowicz D, Fiddes JC \& Abraham JA 1991 The human gene for vascular endothelial growth factor. Journal of Biological Chemistry 266 11947-11954.

Vanderberg LN, Maffini MV, Wadia PR, Sonnenschein C, Rubin BS \& Soto AM 2007 Exposure to environmentally relevant doses of the xenoestrogen bisphenol-A alters development of the fetal mouse mammary gland. Endocrinology 148 116-127.

Yen ML, Su JL, Chien CL, Tseng KW, Yang CY, Chen WF, Chang CC \& Kuo ML 2005 Diosgenin induces hypoxia-inducible factor-1 activation and angiogenesis through estrogen receptor-related phosphatidylinositol 3-kinase/Akt and p38 mitogen-activated protein kinase pathways in osteoblasts. Molecular Pharmacology 68 1061-1073.

Zabik ME \& Schemmel R 1973 Dieldrin storage of obese, normal, and semistarved rats. Archives of Environmental Health 27 25-30.

Zivadinovic D \& Watson CS 2005 Membrane estrogen receptor-alpha levels predict estrogen-induced ERK1/2 activation in MCF-7 cells. Breast Cancer Research 7 R130-R144.

Received in final form 29 October 2007

Accepted 12 November 2007

Made available online as an Accepted Preprint

12 November 2007 